Guoquan Chen, Nan Ning, Lan Li, Huiqun Zhao

\title{
The Current State and Future Directions of Research and Practice in Organizational Learning and Learning Organizations in China
}

\author{
(C) Higher Education Press and Springer-Verlag 2010
}

\begin{abstract}
This article aims to analyze systematically academic papers concerning organizational learning and learning organizations in the China Academic Journals Full-text Database (CAJ) published after 2000. A detailed review was conducted of their main findings, publication time, research methods, subjects (themes), and source of funding to depict the current state of research on organizational learning and learning organizations in China on three different levels, namely organizational, team and individual levels of learning. Based on the comprehensive review of literature, this article proposes future directions for organizational learning research and practice in China. Suggestions are offered to advance further research and practice in China.
\end{abstract}

Keywords organizational learning, learning organizations, team learning,

Translated from Guanli Xuebao 管理学报 (Chinese Journal of Management), 2009, 6(5): 569-579

Guoquan Chen $(\square)$

School of Economics \& Management, Tsinghua University, Beijing 100084, China

E-mail: chengqu@sem.tsinghua.edu.cn

Nan Ning

School of Economics \& Management, Tsinghua University, Beijing 100084, China

E-mail: ningn@sem.tsinghua.edu.cn

Lan Li

Development Research Center of the State Council, Beijing 100010, China

E-mail: lilan@cess.gov.cn

Huiqun Zhao

School of Economics \& Management, Tsinghua University, Beijing 100084, China

E-mail: zhaohq.05@sem.tsinghua.edu.cn 
individual learning, research and practice

\section{Introduction}

Since the reform and opening up in 1978, China's economy has been growing rapidly. As a result of the steady progress in the reform and opening up, economic globalization and increasingly fierce market competition, Chinese enterprises are now facing a more complex and changeable environment. In order to establish and maintain competitiveness, it is essential for these enterprises to enhance the capability of organizational learning and self-renewal. Over the past few years, Chinese researchers and practitioners have become increasingly aware of the importance of organizational learning and learning organizations. Studies have also been conducted from different aspects to examine various issues in the field.

However, what is the current state of research and practice of organizational learning and learning organizations in China? What are promising directions of relevant research in the future? This article aims to find answers to these questions based on a comprehensive literature review and analysis.

\section{Current State and Future Directions of Research}

To gain a better understanding of the current state of research in organizational learning and learning organizations in China, this research first collected all relevant papers published after 2000 in the China Academic Journals Full-text Database (CAJ). Then, it categorized and analyzed these papers on the levels of organizational learning, team learning, and individual learning. By doing so, we hope to discover promising future research directions and promote studies on organizational learning and learning organizations in China.

\subsection{Overview}

\subsubsection{Sample of Research Papers}

Because organizational learning and learning organizations are a multifaceted issue, we will analyze relevant current research at the levels of organization, team, and individual, and explore the relationships among these levels.

With over 8200 different Chinese journals in its collection, the CAJ is now the biggest full-text database of Chinese journal publications in the world, and is continuously updated. Easily distinguishable, data on journal papers are always complete and more reliable than from the conference proceedings. Two 
sub-databases in the CAJ related to organizational learning, namely the Education \& Social Science and Economics \& Management, were chosen as the sources of our sample. We searched papers published in 2000-2008 with "organizational learning," "team learning," or "individual learning" as keywords in "core journals of CAJ" in the two sub-databases. A total of 186 papers were identified. After eliminating irrelevant ones and short ones (less than two pages in length), 147 "valid" papers were collected, including 121 on organizational learning, 17 on team learning, 5 on individual learning, and 4 on the interrelationship among the three levels of learning. Due to the time lag of the two databases, only two articles published in 2008 were collected. Therefore, the time series curve in Fig. 1 ends in 2007.

\subsubsection{Distribution by Years}

According to the yearly distribution of the sampled paper (as shown in Table 1 and Fig. 1), we divide the studies on organizational learning in China into the following phases:

(1) The initial phase (2000-2001). There were only 6 papers concerning organizational learning during year 2000 and 2001. It means that although the theory of organizational learning had been noticed by domestic researchers, it was not taken seriously.

(2) The development phase (2002-2004). Annually, there were 7-8 papers about organizational learning published in academic journals. In this phase, Chinese researchers also started to pay attention to team and individual learning. Organizational learning had attracted wide attention from a number of researchers.

(3) The rapid growth phase (2005-2007). The number of papers published grew rapidly in this phase. A growing number of domestic researchers have started to pay attention to organizational learning.

Table 1 Paper Distribution by Year

\begin{tabular}{lcccccccccr}
\hline \multicolumn{1}{c}{ Research focus } & 2000 & 2001 & 2002 & 2003 & 2004 & 2005 & 2006 & 2007 & 2008 & Total \\
\hline $\begin{array}{l}\text { Organizational } \\
\quad \text { learning }\end{array}$ & 2 & 4 & 7 & 8 & 8 & 17 & 25 & 50 & & 121 \\
$\quad$ Team learning & & & 2 & 1 & 2 & 1 & 5 & 6 & & 17 \\
$\quad \begin{array}{l}\text { Individual learning } \\
\text { Correlations }\end{array}$ & & & & 1 & & 2 & & & 2 & 5 \\
Total & 2 & 4 & 10 & 10 & 10 & 21 & 30 & 58 & 2 & 147 \\
\hline
\end{tabular}

Note: Due to the time lag of the two databases, only 2 articles published in 2008 were collected. 


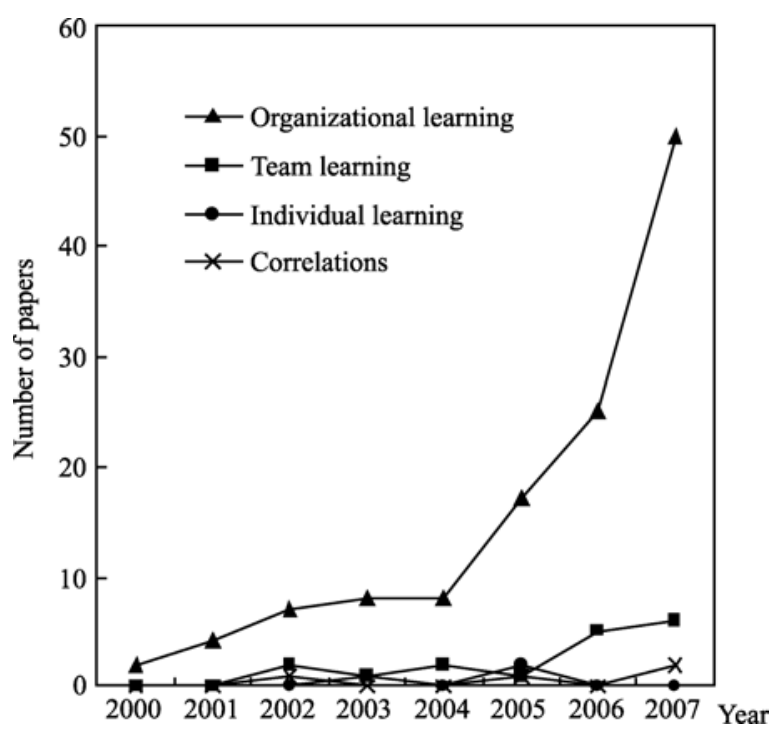

Fig. 1 Research on Organizational Learning and Learning Organizations during 2000-2007

\subsubsection{Research Methods}

Research methods adopted by the sampled papers can be roughly divided into 4 categories: (1) literature review, which presents analysis or comments of the extant research and theories of organizational learning home and abroad, (2) conceptual research, which mainly refers to theoretical approach used to deduct (but not to testify) viewpoints, develop models and research frameworks, etc., (3) quantitative research, which refers to the use of empirical methods to quantitatively analyze proposed models, (4) case study, in which specific enterprises are studied and research conclusions are drawn accordingly. These four categories are divided only for convenience and simplicity. Some papers might fall into more than one categorie. For example, some sampled papers adopted both conceptual and case study methods. Based on the above categorization, we can get a rough picture of study methods used in sampled papers at all levels. As shown in Table 2, 60\% sampled paper adopted the conceptual method and $27 \%$ the quantitative method.

Table 2 Research Methods Adopted by the Sampled Papers

\begin{tabular}{ccccc}
\hline Research method adopted & $\begin{array}{c}\text { Conceptual } \\
\text { research }\end{array}$ & $\begin{array}{c}\text { Quantitative } \\
\text { research }\end{array}$ & $\begin{array}{c}\text { Literature } \\
\text { review }\end{array}$ & $\begin{array}{c}\text { Case } \\
\text { study }\end{array}$ \\
\hline Total number of papers & 91 & 42 & 13 & 8 \\
\hline
\end{tabular}




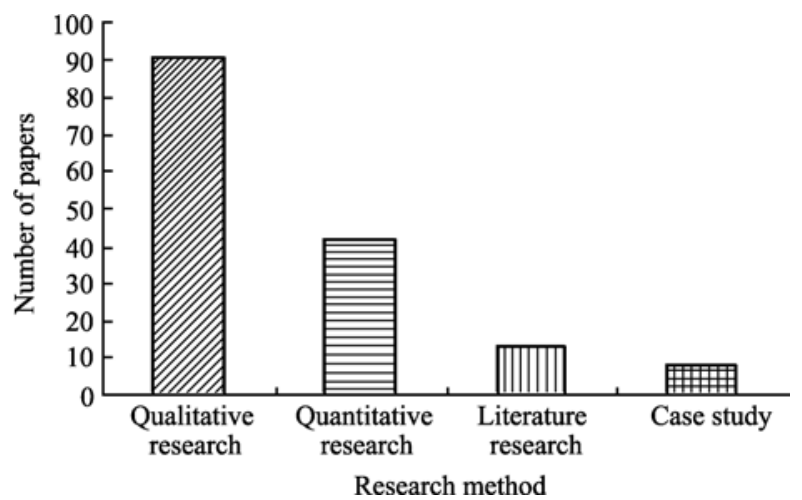

Fig. 2 Research Methods Adopted by the Sampled Papers

\subsubsection{Research Subject}

Similarly, sampled papers are divided into three categories in accordance with their research subjects (themes): (1) organizational learning itself, including its contents, mechanisms, methods, processes, obstacles, measurement, and relevant tools; (2) antecedents of organizational learning, which are to the factors affecting the process or the efficiency of organizational learning; (3) consequences of organizational learning, which are the impact of organizational learning on organizational performance, employee growth and other factors. Detailed analysis on research subject in the sample papers are shown in Table 3 and Fig. 3 as below.

Table 3 Analysis of the Research Subjects of Sampled Papers

\begin{tabular}{cccc}
\hline Research subject & $\begin{array}{c}\text { Organizational } \\
\text { learning itself }\end{array}$ & Antecedents & Consequences \\
\hline Number of papers & 101 & 42 & 38 \\
\hline
\end{tabular}

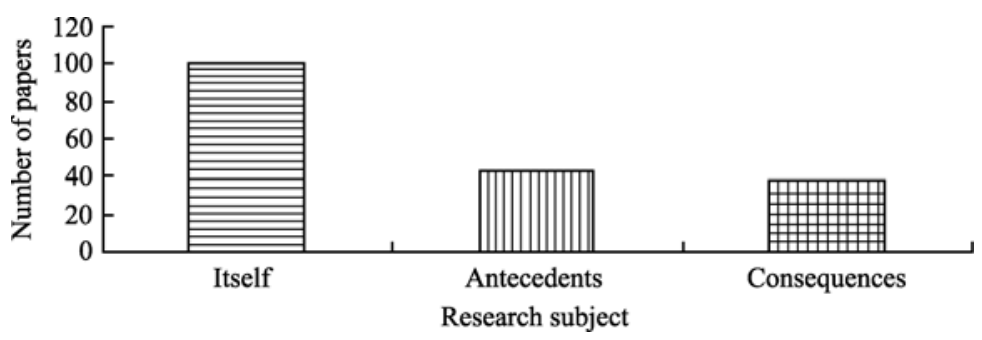

Fig. 3 Research Subjects of Sampled Papers

\subsubsection{Regional Distribution of Authors}

The regional distribution of the authors of sampled paper is shown in Table 4. 
Table 4 Regional Distribution of Authors

\begin{tabular}{lcc||lcc}
\hline \multicolumn{1}{c}{ Region } & $\begin{array}{c}\text { Number of } \\
\text { papers }\end{array}$ & $\begin{array}{c}\text { Percentage } \\
(\%)\end{array}$ & Region & $\begin{array}{c}\text { Number of } \\
\text { papers }\end{array}$ & $\begin{array}{c}\text { Percentage } \\
(\%)\end{array}$ \\
\hline Beijing & 40 & 27 & Chongqing & 3 & 2 \\
Tianjin & 16 & 11 & Liaoning & 2 & 1 \\
Shanghai & 13 & 9 & Heilongjiang & 2 & 1 \\
Shaanxi & 13 & 8 & Jiangxi & 2 & 1 \\
Guangdong & 11 & 7 & Fujian & 1 & 1 \\
Sichuan & 11 & 7 & Hebei & 1 & 1 \\
Jiangsu & 9 & 6 & Henan & 1 & 1 \\
Zhejiang & 6 & 4 & Ningxia & 1 & 1 \\
Anhui & 5 & 3 & Yunnan & 1 & 1 \\
Hubei & 5 & 2 & Shandong & 1 & 1 \\
Hunan & 3 & & & \\
\hline
\end{tabular}

\subsubsection{Sources of Funding for the Sample Papers}

Many sampled papers were sponsored by different programs or national foundations, such as the National Science Fund for Distinguished Young Scholars, the National Natural Science Foundation, the National Social Science Foundation, Humanities and Social Science Foundation of the Ministry of Education, and other foundations at university or regional levels. Specifically, out of the 147 papers, 83 papers $(56.5 \%)$ were sponsored, in which 56 papers (38.1\%) were supported by foundations at the national level. Especially, 43 papers (29.3\%) were supported by the National Natural Science Foundation.

\subsection{Research at Different Levels}

\subsubsection{Research on Organizational-Level Learning}

\subsubsection{Research Methods and Subjects}

As shown in Fig. 4, the number of conceptual research on organizational learning has increased since 2000, while quantitative research has not started increasing until 2005. As a symbol of research development in the field, there appeared several review of studies on organizational level learning during 2006-2007. By comparison, however, case study on organizational level learning has been lacking.

Further analysis of studies on organizational level learning in 2000-2007 
reveals two distinctive features (as shown in Fig. 5): (1) Most of the studies focused on organizational learning itself, neglecting both the learning's antecedents and consequences; (2) conceptual research is most common in papers on organizational learning itself, while both conceptual and quantitative methods are applied in papers on the antecedents and consequences of organizational learning. A plausible explanation might be that studies on the antecedents and consequences of organizational learning might involve testing of causality relationship among different variables, making it more necessary to adopt quantitative methods. By comparison, there have been very few review and case study papers on organizational-level learning.

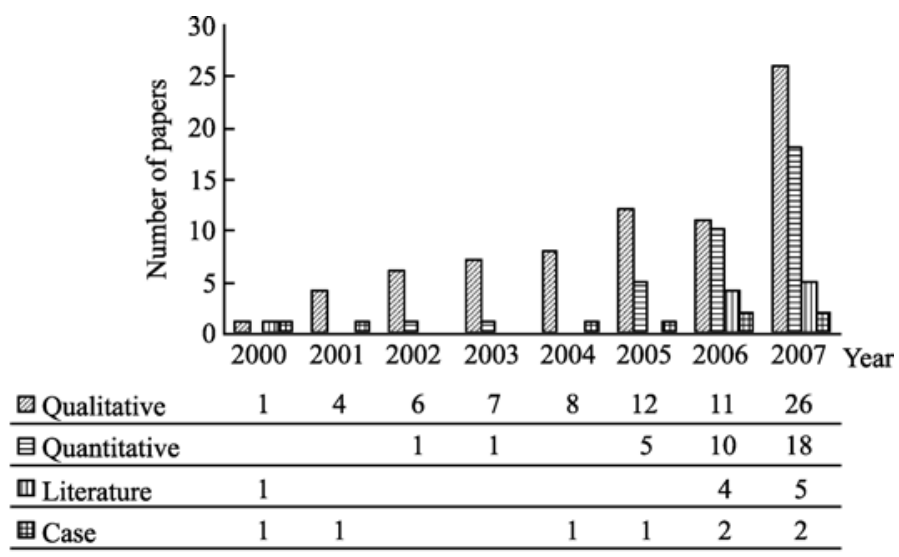

Fig. 4 Research Methods Adopted at the Organizational Level

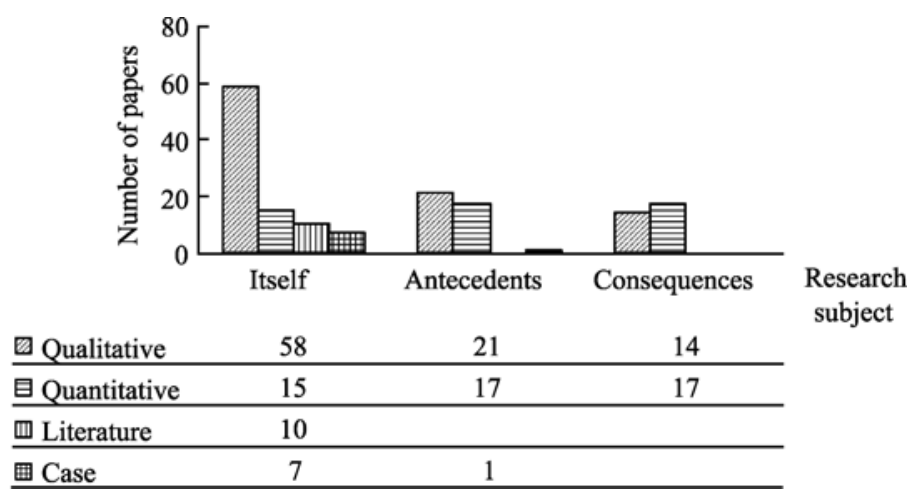

Fig. 5 Research Subject and Methods Adopted by the Organizational-Level Study

\subsubsection{Main Findings at the Organizational Level}

A number of organizational learning models at the organizational level have been 
established. Some of them have been continuously improved and empirically tested by the standardized quantitative methods, while others are just conceptual models developed by means of conceptual or theoretical analysis. Table 5 summarizes the main organizational learning models at the organizational level established by Chinese researchers.

Table 5 Main Models on Organizational Learning

\begin{tabular}{|c|c|c|}
\hline $\begin{array}{l}\text { Research } \\
\text { method }\end{array}$ & Author(s) & Main model(s) \\
\hline $\begin{array}{l}\text { Quantitative } \\
\text { research }\end{array}$ & $\begin{array}{l}\text { Chen and Ma, } \\
\text { 2000; Chen and } \\
\text { Zheng, 2005; } \\
\text { Chen, 2006; } \\
\text { Chen, 2007; } \\
\text { Chen, 2008 }\end{array}$ & $\begin{array}{l}\text { These papers establish a holistic system model of learning } \\
\text { organizations, which includes the learning organizations and } \\
\text { learning capability system model (LO-LCS), and learning } \\
\text { organizations and organizational system model (LO-OS). } \\
\text { The two sub-models are interactive of each other } \\
\text { LO-LCS is composed of the following nine capabilities: } \\
\text { discovering, innovating, selecting, executing, transferring, } \\
\text { reflecting, acquiring knowledge from environment, } \\
\text { contributing knowledge to environment and building } \\
\text { organizational memory. Learning organizations and } \\
\text { organizational learning capability questionnaire (LO-OLCQ) } \\
\text { is developed accordingly ly } \\
\text { LO-OS is composed of five dimensions: (1) development and } \\
\text { learning oriented leadership, (2) robust and excellent } \\
\text { organizational vision and goal, (3) systematic learning } \\
\text { practice and system, (4) common and harmony interest } \\
\text { relationship; and (5) people oriented organizational culture. } \\
\text { Learning organizations and organizational system } \\
\text { questionnaire (LO-OSQ) is developed accordingly } \\
\text { The first LO-LCS Model was established in 2000, and was } \\
\text { improved during 2002 and 2005. The current LO-LCS } \\
\text { Model consists of nine capabilities, namely discovering, } \\
\text { innovating, selecting, executing, transferring, reflecting, } \\
\text { acquiring knowledge from environment, contributing } \\
\text { knowledge to environment and building of organizational } \\
\text { memory }\end{array}$ \\
\hline & $\begin{array}{l}\text { Yu, Fang and } \\
\text { Ling, 2004; Yu, } \\
\text { Fang and Ling, } \\
\text { 2004; Yu, Fang } \\
\text { and Ling, 2006; } \\
\text { Yu, Fang and } \\
\text { Ling, } 2007\end{array}$ & $\begin{array}{l}\text { The model of learning strategies evolution includes three } \\
\text { stages: employee development, imminent business needs, } \\
\text { and new business development } \\
\text { The integrated organizational learning model contains four } \\
\text { levels (namely individual, group, organizational and } \\
\text { inter-organizational levels), four psychological and social } \\
\text { interactions (namely acquirement and production, } \\
\text { interpretation, integration, and institutionalization) and two } \\
\text { information or knowledge processes (namely feedback and } \\
\text { feed forward learning) } \\
\text { The multi-dimensional organizational learning model includes } \\
\text { six constructs, namely inter-organizational learning, } \\
\text { organizational level learning, collective level learning, } \\
\text { individual level learning, exploitation learning, and } \\
\text { exploration learning }\end{array}$ \\
\hline
\end{tabular}


(Continued)

\begin{tabular}{|c|c|c|}
\hline $\begin{array}{l}\text { Research } \\
\text { method }\end{array}$ & Author(s) & Main model(s) \\
\hline \multirow{4}{*}{$\begin{array}{l}\text { Conceptual } \\
\text { research }\end{array}$} & $\begin{array}{l}\text { Tang and } \mathrm{He}, \\
2005\end{array}$ & $\begin{array}{l}\text { The knowledge fermenting model: initial knowledge, } \\
\text { maternal knowledge, knowledge enzyme, environment } \\
\text { knowledge and information tools, advanced knowledge, and } \\
\text { knowledge fermenting bar }\end{array}$ \\
\hline & $\begin{array}{l}\text { Zhang and Yu, } \\
2005\end{array}$ & $\begin{array}{l}\text { The multi-loop model of organizational learning based on } \\
\text { individual learning: R1—individual learning cycle } \\
\text { R2-group or team learning cycle; R3 - the bridge between } \\
\text { R2 and R4; and R4 - organizational learning cycle }\end{array}$ \\
\hline & $\begin{array}{l}\text { Zhang and } \\
\text { Zhang, } 2005\end{array}$ & $\begin{array}{l}\text { The two-dimension model of inter-organizational learning } \\
\text { knowledge transferring and experience accumulation }\end{array}$ \\
\hline & $\begin{array}{l}\text { Chu and Tang, } \\
\text { 2006) }\end{array}$ & $\begin{array}{l}\text { The quantum learning model: the first phase - the quantum } \\
\text { turbulence storage; the second phase - the learning energy } \\
\text { transition; the third phase - the high-energy state; and the } \\
\text { fourth phase - the quantum decay phase }\end{array}$ \\
\hline
\end{tabular}

Researchers also studied the factors that affect organizational learning, including external environment, internal factors, human resources management, organizational culture, information technology and so on. Table 6 presents some of the main influencing factors of organizational learning.

Table 6 Antecedents and Consequences of Organizational Learning

\begin{tabular}{|c|c|c|c|}
\hline Author(s) & Independent variable & Dependent variable & Main research results \\
\hline $\begin{array}{l}\text { Chen, } \\
2001\end{array}$ & Environment & $\begin{array}{l}\text { Organizational } \\
\text { learning }\end{array}$ & $\begin{array}{l}\text { To illustrate the dynamic organization- } \\
\text { environment relationship, the "tai-ji } \\
\text { tu" (diagram of the supreme ultimate) } \\
\text { has been adopted as an organizational } \\
\text { learning tool to keep organization- } \\
\text { environment relationship dynamically } \\
\text { appropriate }\end{array}$ \\
\hline $\begin{array}{l}\text { Chen, } \\
2004\end{array}$ & $\begin{array}{l}\text { Organizational } \\
\text { structure }\end{array}$ & $\begin{array}{l}\text { Organizational } \\
\text { learning capability }\end{array}$ & $\begin{array}{l}\text { Five functional characteristics (namely } \\
\text { information/intelligence function, } \\
\text { innovation function, learning/training } \\
\text { function, knowledge management } \\
\text { function, and change/crisis } \\
\text { management function) and four form } \\
\text { characteristics (namely team-based/ } \\
\text { net-worked, flat, market/customer } \\
\text { oriented, elastic/reconfigurable) } \\
\text { which would affect the organizational } \\
\text { learning capability have been put } \\
\text { forward }\end{array}$ \\
\hline
\end{tabular}


(Continued)

\begin{tabular}{|c|c|c|c|}
\hline Author (s) & Independent variable & Dependent variable & Main research results \\
\hline $\begin{array}{l}\text { Wei, Zhong } \\
\text { and Zhao, } \\
2005\end{array}$ & Information technology & $\begin{array}{l}\text { Organizational } \\
\text { memory, Degree of } \\
\text { information } \\
\text { sharing, } \\
\text { Communication in } \\
\text { organizational } \\
\text { learning and } \\
\text { operational } \\
\text { efficiency of } \\
\text { organizations }\end{array}$ & $\begin{array}{l}\text { Information technology has a } \\
\text { positive impact on organizational } \\
\text { memory, degree of information } \\
\text { sharing, communication in } \\
\text { organizational learning, and } \\
\text { operational efficiency of } \\
\text { organizations }\end{array}$ \\
\hline $\begin{array}{l}\text { K } \\
\text { Yuan, Yao } \\
\text { and Zheng, } \\
2005\end{array}$ & $\begin{array}{l}\text { Knowledge inertia: group } \\
\text { lost, individual lost, } \\
\text { dispersion of } \\
\text { organizational matters } \\
\text { and retardation of results, } \\
\text { fear of change, and } \\
\text { cost-income dissonance }\end{array}$ & $\begin{array}{l}\text { Organizational } \\
\text { learning }\end{array}$ & $\begin{array}{l}\text { The Knowledge inertia has impact } \\
\text { on organizational learning }\end{array}$ \\
\hline $\begin{array}{l}\text { Chen and } \\
\text { Zheng, } \\
2005\end{array}$ & $\begin{array}{l}\text { Perceived environmental } \\
\text { change and the extent } \\
\text { of cooperative goal } \\
\text { interdependence among } \\
\text { employees }\end{array}$ & $\begin{array}{l}\text { The facilitating } \\
\text { factors for } \\
\text { organizational } \\
\text { learning }\end{array}$ & $\begin{array}{l}\text { It is found that different levels of } \\
\text { perceived environmental change } \\
\text { and the extent of cooperative goal } \\
\text { interdependence among } \\
\text { employees within company will } \\
\text { lead to significantly different } \\
\text { degree of facilitating factors }\end{array}$ \\
\hline Xie, 2005 & Market orientation & $\begin{array}{l}\text { Organizational } \\
\text { learning }\end{array}$ & $\begin{array}{c}\text { Market orientation has a positive } \\
\text { impact on organizational learning }\end{array}$ \\
\hline $\begin{array}{l}\text { Peng, Xie } \\
\text { and Chen, } \\
2005\end{array}$ & $\begin{array}{l}\text { Environmental } \\
\text { turbulence }\end{array}$ & $\begin{array}{l}\text { Organizational } \\
\text { learning }\end{array}$ & $\begin{array}{l}\text { Environmental turbulence has a } \\
\text { positive impact on organizational } \\
\text { learning }\end{array}$ \\
\hline $\begin{array}{l}\text { Chen and } \mathrm{Li} \text {, } \\
2006\end{array}$ & $\begin{array}{l}\text { Ownership type, size, } \\
\text { region and industry, } \\
\text { employee quality and } \\
\text { employee training of } \\
\text { enterprises }\end{array}$ & $\begin{array}{l}\text { Organizational } \\
\text { learning capability }\end{array}$ & $\begin{array}{l}\text { The ownership type of enterprises, } \\
\text { size, region, industry, employee } \\
\text { quality and employee training } \\
\text { have significant impact on } \\
\text { organizational learning capability }\end{array}$ \\
\hline $\begin{array}{l}\text { Hu and Pan, } \\
2006\end{array}$ & $\begin{array}{l}\text { The degree of knowledge } \\
\text { overlap }\end{array}$ & $\begin{array}{l}\text { Knowledge transfer } \\
\text { efficiency and } \\
\text { learning capability }\end{array}$ & $\begin{array}{l}\text { The degree of knowledge overlap } \\
\text { has impact on knowledge transfer } \\
\text { efficiency and learning capability }\end{array}$ \\
\hline $\begin{array}{l}\text { Xie, Wu, } \\
\text { Wang and } \\
\text { Ge, } 2006\end{array}$ & $\begin{array}{l}\text { External factors, internal } \\
\text { factors }\end{array}$ & $\begin{array}{l}\text { Organizational } \\
\text { learning }\end{array}$ & $\begin{array}{l}\text { The factors affecting organizational } \\
\text { learning include external factors } \\
\text { (change of socio-economic value, } \\
\text { social movements, transformation } \\
\text { of social and economic system, } \\
\text { marketing signals, imagination of } \\
\text { technology vision and } \\
\text { technological development) and } \\
\text { internal factors (individual level, } \\
\text { team level, organizational level) }\end{array}$ \\
\hline
\end{tabular}

(To be continued) 
(Continued)

\begin{tabular}{|c|c|c|c|}
\hline Author(s) & Independent variable & Dependent variable & Main research results \\
\hline $\begin{array}{l}\text { Lu, Yue } \\
\text { and Liao, } \\
2006\end{array}$ & $\begin{array}{l}\text { The contact rate } \\
\text { between members, } \\
\text { members' knowledge } \\
\text { forgotten rate, number } \\
\text { of members in } \\
\text { co-operation and } \\
\text { learning, and } \\
\text { members' transfer rate }\end{array}$ & $\begin{array}{l}\text { Tacit knowledge } \\
\text { transfer }\end{array}$ & $\begin{array}{l}\text { The contact rate between } \\
\text { members, members' knowledge } \\
\text { forgotten rate, number of } \\
\text { members in co-operation and } \\
\text { learning and members' transfer } \\
\text { rate all have some impact on } \\
\text { tacit knowledge transfer }\end{array}$ \\
\hline $\begin{array}{l}\text { Dai and } \\
\text { Zhao, } \\
2007\end{array}$ & Cultural differences & $\begin{array}{l}\text { Organizational } \\
\text { learning processes, } \\
\text { organizational } \\
\text { learning climate, } \\
\text { creation of learning } \\
\text { opportunities, and } \\
\text { establishment of a } \\
\text { common vision }\end{array}$ & $\begin{array}{l}\text { The authors studied the } \\
\text { differences between Chinese } \\
\text { and Dutch enterprises in terms } \\
\text { of organizational learning } \\
\text { processes, organizational } \\
\text { learning climate, creation of } \\
\text { learning opportunities, and } \\
\text { establishment of a common } \\
\text { vision }\end{array}$ \\
\hline Zhou, 2007 & $\begin{array}{l}\text { The formation of family } \\
\text { business, tenure of } \\
\text { general manager }\end{array}$ & $\begin{array}{l}\text { Inter-organizational } \\
\text { learning behavior }\end{array}$ & $\begin{array}{l}\text { The inter-organizational learning } \\
\text { behavior of authoritarian-type } \\
\text { family business is stronger than } \\
\text { non-authoritarian type family } \\
\text { business. With the increased } \\
\text { popularity of the general } \\
\text { manager, the inter- } \\
\text { organizational learning behavior } \\
\text { will first increase and then } \\
\text { decrease }\end{array}$ \\
\hline $\begin{array}{l}\text { Chen, Li } \\
\text { and Xie, } \\
2007\end{array}$ & $\begin{array}{l}\text { The level of } \\
\text { technological } \\
\text { differences }\end{array}$ & $\begin{array}{l}\text { Inter-organizational } \\
\text { transparency level } \\
\text { and absorptive } \\
\text { capacity }\end{array}$ & $\begin{array}{l}\text { The level of inter-organizational } \\
\text { technological difference affects } \\
\text { firms' transparency level and } \\
\text { absorptive capacity, which in } \\
\text { turn affect the efficiency of } \\
\text { inter-organizational learning }\end{array}$ \\
\hline Chen, 2007 & $\begin{array}{l}\text { Learning oriented } \\
\text { human resource } \\
\text { management }\end{array}$ & $\begin{array}{l}\text { Organizational } \\
\text { learning capability }\end{array}$ & $\begin{array}{l}\text { The learning oriented human } \\
\text { resource management has a } \\
\text { positive impact on } \\
\text { organizational learning } \\
\text { capability }\end{array}$ \\
\hline $\begin{array}{l}\text { Yu, zheng, } \\
\text { Fang and } \\
\text { Ling, } \\
2007\end{array}$ & $\begin{array}{l}\text { The facilitating factors } \\
\text { of organizational } \\
\text { learning within an } \\
\text { organization: } \\
\text { continuous } \\
\text { development, } \\
\text { organizational support, } \\
\text { openness \& } \\
\text { cooperation, and } \\
\text { respect multiplicity }\end{array}$ & $\begin{array}{l}\text { Organizational } \\
\text { learning }\end{array}$ & $\begin{array}{l}\text { The facilitating factors could } \\
\text { improve receiving knowledge } \\
\text { from outside, formal spread of } \\
\text { knowledge, transformational } \\
\text { and collective learning. These } \\
\text { would have significant } \\
\text { implications for management } \\
\text { practice and managing } \\
\text { organizational learning }\end{array}$ \\
\hline $\begin{array}{l}\text { Liu and } \\
\text { Gao, } 2007\end{array}$ & $\begin{array}{l}\text { Inter-organizational } \\
\text { trust }\end{array}$ & Technical learning & $\begin{array}{l}\text { Inter-organizational trust } \\
\text { promotes technical learning }\end{array}$ \\
\hline
\end{tabular}


Study on the organizational-level learning also involves the outcomes of organizational learning. The most accepted conclusions include:

First, organizational learning has a positive impact on organizational performance (Chen and Zheng, 2005; Xie, 2005; Chen et al., 2006; Liu and Gao, 2007; Yu, Fang and Ling, 2007; Liu, 2007; Li, 2007). In a survey on 2035 Chinese companies, Chen (2006) found that learning capability has a significant and positive impact on the effectiveness of enterprise innovation, competitiveness in finance, operation, customer, and employee and integrated competitiveness. Among them, the impact on enterprise innovation effectiveness is most significant $\left(R^{2}=0.513\right)$, followed by integrated competitiveness $\left(R^{2}=\right.$ $0.429)$, and competitiveness in employee $\left(R^{2}=0.354\right)$, operation $\left(R^{2}=0.344\right)$, customer $\left(R^{2}=0.309\right)$ and finance $\left(R^{2}=0.214\right)$. This shows that enterprises need to enhance their organizational learning capability in order to improve the effectiveness of organizational innovation and competitiveness (Chen and $\mathrm{Li}$, 2006).

Second, organizational learning affects the core competence of an organization (Wu, 2003; Xie, Wu, Wang and Ge, 2006; Zhu, Wang and Lan, 2007). Yu, Fang and Ling (2007) studied the impact of organizational learning on employee satisfaction, affective commitment and intention of resign. Xie (2005) identified the mediating role that organizational learning plays between market orientation and organizational performance. Liu and Chen (2006) found that market orientation affects organizational learning and innovation which indirectly influences the organizational performance. Jiang and Zhao (2006) put forward a structural model in which organizational learning acts as a mediating variable between social capital as well as corporate entrepreneurship and organizational performance. Li, Ren and Wei (2006) found that some organizational learning methods have significant influences on management innovation performance.

\subsubsection{Research on Team Level Learning}

\subsubsection{Methods and Subjects}

There are only 17 sampled papers on organizational learning at the team level. As shown in Fig. 6, most of the papers focusing on the team learning itself adopted the conceptual research method, while most papers on the antecedents of team-level learning adopted the conceptual research method. Moreover, there is hardly any case study on organizational learning at the team level. These results show that team learning as a whole has not received enough attention from the academia. 


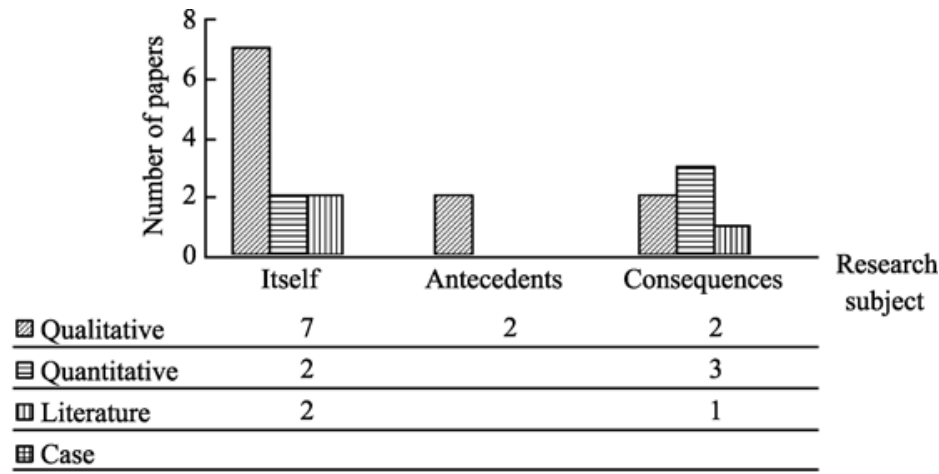

Fig. 6 Research Subject and Methods Adopted by the Team-Level Study

\subsubsection{Main Findings}

Table 7 presents the main models, viewpoints and conclusions on organizational

Table 7 Main Models of Team-Level Learning

\begin{tabular}{|c|c|c|}
\hline Main subject & Author(s) & Main model, view and conclusion \\
\hline $\begin{array}{l}\text { Team learning } \\
\text { capability } \\
\text { (TLC) Model }\end{array}$ & Chen, 2007 & $\begin{array}{l}\text { The article defined the concepts of team learning and } \\
\text { learning team and identified nine team learning behaviors } \\
\text { and capabilities, including discovering, innovating, } \\
\text { selecting, executing, transferring, Reflecting, acquiring } \\
\text { knowledge from environment, contributing knowledge to } \\
\text { environment and building organizational memory. Team } \\
\text { learning capability questionnaire (TLCQ) was also } \\
\text { established in the article }\end{array}$ \\
\hline \multirow{3}{*}{$\begin{array}{l}\text { Construction of } \\
\text { learning team }\end{array}$} & $\begin{array}{l}\text { Liu, Zhang and } \\
\text { Zhan, } 2002\end{array}$ & $\begin{array}{l}\text { The learning model of product development team consists } \\
\text { of: (1) knowledge management strategies and measures, } \\
\text { (2) performance evaluation and incentive system, (3) } \\
\text { flexible organizational strategy, (4) team stability, (5) } \\
\text { systematic degree of product development, } \\
\text { (6)competence of managers, and (7) the recognition of } \\
\text { the organizational goals }\end{array}$ \\
\hline & $\begin{array}{l}\text { Liao, } \mathrm{Hu} \text { and } \\
\text { Jin, } 2006\end{array}$ & $\begin{array}{l}\text { The pyramid model of virtual team learning consists of } \\
\text { team members (personalized, multi-roles, co-leadership, } \\
\text { motivation), extensive contact (multi-media, } \\
\text { communication, trust), resource sharing (practice, the } \\
\text { database), and shared vision (goals) }\end{array}$ \\
\hline & $\begin{array}{l}\text { Hao and Luo, } \\
\text { 2003; Feng } \\
\text { and Luo, } \\
2005 ; \text { Luo, } \\
2006\end{array}$ & $\begin{array}{l}\text { The concept of virtual learning team was defined. The } \\
\text { construction of virtual learning teams is composed of the } \\
\text { following steps: (1) the authority of the core is the key, } \\
\text { (2) adjustment and synergy is guarantee, (3) the spread of } \\
\text { knowledge is an important means to expand learning } \\
\text { region, and (4) dynamic update is an effective measure to } \\
\text { improve the overall level of virtual learning team. The } \\
\text { human resources of virtual learning teams can be divided } \\
\text { into core employees, temporary employees and partners. } \\
\text { The systematic structure solution to partner selection is } \\
\text { also put forward }\end{array}$ \\
\hline
\end{tabular}


learning at the team level. By comparison, the number of papers on the antecedents and consequences of team-level learning is relatively small (see Table 8).

Table 8 Main Findings of the Antecedents and Consequences of the Team-Level Learning

\begin{tabular}{|c|c|c|c|c|}
\hline & Author(s) & Independent variable & $\begin{array}{c}\text { Dependent } \\
\text { variable }\end{array}$ & Main findings \\
\hline \multirow{3}{*}{ Antecedents } & $\begin{array}{l}\text { Tang and } \\
\text { Zhu, } \\
2006\end{array}$ & $\begin{array}{l}\text { The structural factors, } \\
\text { technical factors, and } \\
\text { peripheral factors of } \\
\text { virtual team }\end{array}$ & $\begin{array}{l}\text { Effectiveness } \\
\text { of team } \\
\text { learning } \\
\text { (learning } \\
\text { task, team } \\
\text { health) }\end{array}$ & $\begin{array}{l}\text { Structural, technical, and } \\
\text { peripheral factors will affect } \\
\text { the virtual team's process and } \\
\text { mode of learning, the latter in } \\
\text { turn has a direct impact on the } \\
\text { effectiveness of learning. The } \\
\text { relationships among virtual } \\
\text { team members and social } \\
\text { cognitive factors will play a } \\
\text { mediating role between } \\
\text { learning process and learning } \\
\text { effectiveness }\end{array}$ \\
\hline & $\begin{array}{l}\text { Tang and } \\
\text { Wang, } \\
2007\end{array}$ & $\begin{array}{l}\text { Social cognitive factors } \\
\text { such as self-efficacy } \\
\text { (general self-efficacy, } \\
\text { virtual self-efficacy) } \\
\text { and goal orientation } \\
\text { (learning orientation, } \\
\text { performance } \\
\text { orientation, avoidance } \\
\text { orientation) }\end{array}$ & $\begin{array}{l}\text { Effectiveness } \\
\text { of virtual } \\
\text { team leaning } \\
\text { (skill } \\
\text { improvement, } \\
\text { team task and } \\
\text { team } \\
\text { well-being) }\end{array}$ & $\begin{array}{l}\text { The results reveal that virtual } \\
\text { team efficacy and goal } \\
\text { orientation have a positive } \\
\text { effect on learning } \\
\text { effectiveness, and attitude } \\
\text { towards virtual team learning } \\
\text { and team trust have a } \\
\text { meditative or direct effect on } \\
\text { the effectiveness of virtual } \\
\text { team learning }\end{array}$ \\
\hline & $\begin{array}{l}\text { Zhao, } \\
\text { Chen } \\
\text { and } \mathrm{Fu} \text {, } \\
2008\end{array}$ & $\begin{array}{l}\text { Factors promoting } \\
\text { learning motivation } \\
\text { (perceived usefulness, } \\
\text { conscientiousness); } \\
\text { Factors reducing } \\
\text { learning resistance } \\
\text { (psychological safety } \\
\text { and agreeableness) }\end{array}$ & $\begin{array}{l}\text { Team learning } \\
\text { capability }\end{array}$ & $\begin{array}{l}\text { The two psychological factors } \\
\text { would influence team } \\
\text { members' decision concerning } \\
\text { participation in team learning } \\
\text { (whether to participate or the } \\
\text { degree of participation) and } \\
\text { affect team learning capability } \\
\text { as a whole }\end{array}$ \\
\hline \multirow[b]{2}{*}{ Consequences } & $\begin{array}{l}\text { Xiao, } \\
2004\end{array}$ & $\begin{array}{l}\text { The three-dimensional } \\
\text { feature structure of } \\
\text { learning team: team } \\
\text { learning, team role and } \\
\text { team empowerment }\end{array}$ & $\begin{array}{l}\text { Team } \\
\text { effectiveness }\end{array}$ & $\begin{array}{l}\text { The three-dimensional feature } \\
\text { structure of learning team has a } \\
\text { positive impact on the } \\
\text { effectiveness of a learning } \\
\text { team }\end{array}$ \\
\hline & $\begin{array}{l}\text { Su and } \\
\text { Shi, } \\
2004\end{array}$ & $\begin{array}{l}\text { Interpersonal factors: } \\
\text { the degree that team } \\
\text { members involved in } \\
\text { learning behavior, } \\
\text { psychological safety, } \\
\text { authority structure of } \\
\text { the leader }\end{array}$ & $\begin{array}{l}\text { Team learning } \\
\text { behavior and } \\
\text { teamwork } \\
\text { effectiveness }\end{array}$ & $\begin{array}{l}\text { Team members' view of } \\
\text { interpersonal relationship and } \\
\text { the authority structure of team } \\
\text { leader will affect team learning } \\
\text { behavior and teamwork } \\
\text { effectiveness }\end{array}$ \\
\hline
\end{tabular}




\begin{tabular}{|c|c|c|c|c|}
\hline & Author(s) & $\begin{array}{l}\text { Independent } \\
\text { variable }\end{array}$ & $\begin{array}{c}\text { Dependent } \\
\text { variable }\end{array}$ & Main findings \\
\hline \multirow[b]{2}{*}{ Consequences } & Chen, 2007 & $\begin{array}{l}\text { Team learning } \\
\text { capability }\end{array}$ & $\begin{array}{l}\text { Team } \\
\text { performance }\end{array}$ & $\begin{array}{l}\text { Team learning capability is } \\
\text { positively correlated to the team } \\
\text { performance }\end{array}$ \\
\hline & $\begin{array}{l}\text { Shi, } \\
\text { Cheng \& } \\
\text { Li, } 2007\end{array}$ & $\begin{array}{l}\text { Learning } \\
\text { capability, } \\
\text { learning } \\
\text { platform, } \\
\text { learning utility } \\
\text { and learning } \\
\text { atmosphere }\end{array}$ & $\begin{array}{l}\text { Diffusion of } \\
\text { team } \\
\text { knowledge }\end{array}$ & $\begin{array}{l}\text { The enrich of learning capability, } \\
\text { improvement of learning } \\
\text { platform, overcome of learning } \\
\text { obstacles and cultivation of } \\
\text { learning atmosphere can } \\
\text { facilitate the diffusion of team } \\
\text { knowledge }\end{array}$ \\
\hline
\end{tabular}

\subsubsection{Current Research of Individual-level Learning}

\subsubsection{Research Method and Subject}

Five sampled papers focus on organizational learning at the individual level. Three out of five belong to the conceptual research and the other two are conceptual research. As the number of research on the individual-level organizational leaning is still relatively small (research on individual learning in the filed of education and psychology are not discussed in this paper), there are hardly literature review or case study concerning individual-level learning. More detailed analysis concerning research on individual level learning is presented in Fig. 7.

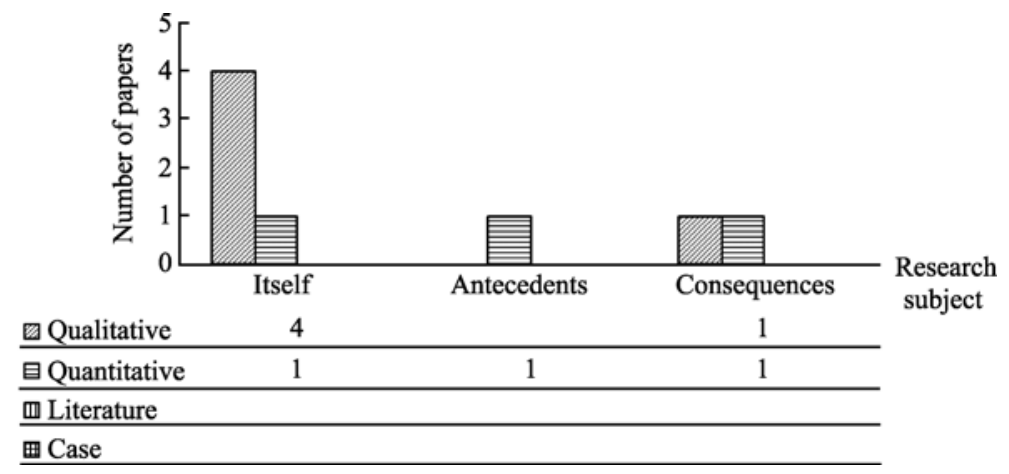

Fig. 7 Research Subject and Methods Adopted by Paper concerning Organizational-Level Learning

\subsubsection{Main Findings on Individual Level}

Table 9 presents major findings of organizational learning at the individual level 
conducted by domestic researchers.

Table 9 Main Findings at the Individual Level

\begin{tabular}{|c|c|c|}
\hline Subjects & Author(s) & Main Views and Findings \\
\hline \multirow{2}{*}{$\begin{array}{l}\text { Individual } \\
\text { learning } \\
\text { itself }\end{array}$} & Chen, 2003 & $\begin{array}{l}\text { The article establishes the knowledge source model } \\
\text { consisting of four methods, namely experiencing, } \\
\text { communicating, reading and reflecting. The specific steps } \\
\text { and key points for using each kind of method are } \\
\text { developed to improve both the effectiveness and } \\
\text { efficiency and knowledge acquisition and transferring. } \\
\text { Based on the model, process for managing both the } \\
\text { knowledge acquisition and transferring was developed }\end{array}$ \\
\hline & Chen, 2008 & $\begin{array}{l}\text { The research on individual learning is briefly reviewed. The } \\
\text { concept of individual learning is put forward. The } \\
\text { definitions of nine behaviors and nine capabilities for } \\
\text { individual learning are established. The individual } \\
\text { learning capability questionnaire (ILCQ) with good } \\
\text { reliability and validity is also developed }\end{array}$ \\
\hline Antecedents & $\begin{array}{l}\text { Yuan, Yao } \\
\text { and } \\
\text { Zheng, } 2005\end{array}$ & $\begin{array}{l}\text { The knowledge inertia would affect individual's learning of } \\
\text { new knowledge. The influencing factors of knowledge } \\
\text { inertia are (1) recognition of existing knowledge, (2) } \\
\text { willing to accept the "new things", (3) the amount of } \\
\text { "outline" exists in memory, (4) the possibility and cost of } \\
\text { verifying new knowledge. Some resolutions to deal with } \\
\text { knowledge inertia have been put forward, and the } \\
\text { pertinacity and reiteration of knowledge inertia are also } \\
\text { pointed out }\end{array}$ \\
\hline Consequences & Chen, 2008 & $\begin{array}{l}\text { The article discovers a significant positive correlation } \\
\text { among individual learning capability, individual task and } \\
\text { contextual performance }\end{array}$ \\
\hline
\end{tabular}

\subsection{Future Directions}

Although Chinese researchers have made achievements in studying organizational learning and learning organizations, many problems remain to be solved. Below, the authors put forward some advice on the future direction of organizational learning research.

\subsubsection{Research Subjects}

Research on organizational, team and individual learning should be strengthened, particularly learning at the team and individual level. Specifically, more attention should be paid to the research on organizational learning at the organizational level from the following aspects: the mechanism and approaches by which an organization learns from experience, mechanism and approaches of crisis-oriented learning, organizational learning-oriented knowledge management 
system, the complex relationship between organizational learning and its antecedents (e.g., internal features and characteristics of the external environment) and consequences (such as a variety of organizational performance and members' satisfaction). At the team level, we should systematically explore the factors which have impacts on team learning (such as the diversities of team goal, knowledge, experience and personality diversity, interaction among team members, the style of team leadership, the team's internal management and external border management), as well as the impacts of team learning itself (such as team performance and team members' satisfaction). At the individual level, more efforts should be spent on exploring the inherent mechanism and rules of individual learning (including both managers and employees) under a business environment, the relationship among individual learning, its antecedents (e.g., personality, values, EQ, attitude, experience, team atmosphere) and consequences (such as individual performance, satisfaction and development potential), and the specific methods to improve individual learning. Moreover, we also need to systematically explore the interaction among these three levels of learning. For example, enterprise leaders need to be more aware of how to effectively improve their own learning capability and adaptability from different sources and transfer these individual-level capabilities into learning capabilities at the team or organizational levels so that they can enhance the learning capabilities of the entire team or organization. At the same time, we also need to explore how to use the overall learning atmosphere and resources to effectively influence each team and individual in an organization to improve the learning efficiency of all members and their learning performance.

\subsubsection{Research Methods}

Each research method has its own strengths and weaknesses. A combination of different research methods might help gain a better understanding of the learning mechanism and the inter-relationship among different learning-related variables. By comparison, case study method is suitable for collecting first-hand data and gaining a deeper understanding of the focused issue and its relationships with the other factors. The experimental approach is more suitable for simplification, precise control of the problem under study as well as identification of the main laws underlying the problem under study. The combination of questionnaire survey and statistical analysis can be used to grasp a more complete picture and identify a universal law. It is also a suitable method for comparisons among

different types of research subjects. In the course of statistical analysis, the hierarchical linear model (HLM) is often used for inter-level research.

\subsubsection{Research Goal and Orientation}

In addition to continuously exploring organizational learning from theoretic 
perspectives, we need to strengthen practice-oriented research in the field. For example, what specific measures, effective tools and methods should be taken to enhance organizational, team and individual learning capability? What are the specific steps taken to develop learning team and learning organizations? What specific measures should be taken to promote the real effects of organizational, team and individual learning on organizational, team and individual performance? Only by strengthening the practice-oriented research, could we make the concept and knowledge of organizational learning and learning organizations more generally accepted by people and exert more positive impact on the national economic and social development.

\section{Current State and Directions of Practice}

Since the concepts of organizational learning and learning organizations were introduced into China in the 1990s, a lot of Chinese enterprises have conducted activities to promote organizational learning and have achieved certain progress. To keep abreast of the latest progress in organizational learning in Chinese enterprises, gain a better understanding of the problems concerning organizational learning facing Chinese enterprises, and find out the impact of organizational learning on enterprise innovation performance and competitiveness, the Chinese Entrepreneurs Survey System (CESS) of the State Council Development Research Center used Chen's organizational learning capability model, evaluation questionnaires (OLCQ) and calculation methods to carry out a large-scale survey in 10000 randomly-selected Chinese enterprises. 3 583 questionnaires were returned, including 3511 valid ones (valid reply rate $=$ $35.1 \%)$. Among which, 2305 were used in the final analysis. Based on these survey data, status quo, problems of Enterprise learning and their impacts on enterprise innovation and Competitiveness were discussed by Chen and $\mathrm{Li}$ (2006). Below, we summarize in brief the current state as follows:

(1) Enterprise managers are now more aware of "organizational learning" and "learning organizations". Most of the interviewed managers are now more aware of the two concepts. For example, data showed that $22.6 \%$ of the interviewed managers said they were very familiar with the two concepts, $59.8 \%$ quite familiar, $17 \%$ were not very familiar, and only $0.6 \%$ said they had never heard of the two concepts. However, the two authors' survey also revealed that some managers were not clear about the connotations of the two concepts. Therefore, more efforts should be spent on helping practitioners gain a more accurate understanding of the two concepts in the future.

(2) Chinese enterprises' organizational learning capability as a whole is at the mid to upper level, but some capabilities (especially the capability of building organizational memory) need to be further improved. We should also promote the sharing and co-developing of learning experience among different types of 
enterprises. According to the Organizational Learning Capability Model, learning capability can be divided into nine "sub-capabilities," namely "discovering, innovating, selecting, executing, transferring, reflecting, acquiring knowledge from environment, contributing knowledge to environment, and building organizational memory." We use the weighted average of these nine sub-capabilities to produce the "integrated organizational learning capability." The degree of organizational learning is divided into 7 levels, ranging from level 1 (very weak) to level 7 (very strong). The higher the level, the stronger an enterprise's learning capability. According to the self-evaluation among top managers, the average level of the integrated organizational learning capability of Chinese enterprise is 5.15. Specifically, the executing capability is 5.34, reflecting capability 5.33 , transferring capability 5.30 , selecting capability 5.29 , innovating capability 5.19 , discovering capability 5.18 , capability to acquire knowledge from environment 5.15, building organizational memory 4.71, and contributing knowledge to environment 4.47. These data show that Chinese enterprises should emphasize on building a mutual-sharing organizational memory, as shown in Table 10.

In addition, there is a significant difference between varied types of enterprises in organizational learning: 1) There are significant differences in integrated organizational learning capability, discovering capability, innovating capability, selecting capability and the capability to acquire knowledge from environment among different types of enterprises. For example, non-state-owned enterprises are usually better than state-owned enterprises in these learning-related capabilities. 2) Enterprises of different size have significant differences in the nine learning-related sub-capabilities. Generally speaking, the bigger the size of an enterprise, the stronger the organizational learning capability. 3) Enterprises in different regions have significant differences in terms of transferring capability, capability to acquire knowledge and building organizational memory. Data show that enterprises in the eastern and central regions demonstrate stronger learning capabilities than enterprises in western regions. 4) Enterprises in different industries have different capabilities in acquiring and transferring knowledge. Particularly, enterprises from the real estate industry have the strongest capability to acquire knowledge and transmit information, while enterprises in the computer services and software industry are good at contributing knowledge to surrounding environment. These results indicate that different learning capability gaps do exist between different types of enterprises. We therefore need to enhance the sharing of learning experience among different types of enterprises.

(3) Enterprises have many ways to acquire knowledge from external environment and share knowledge in internal environment. We need to enhance the efficiency of knowledge acquisition and sharing in the future.

As shown in Table 11, enterprises have many ways to acquire knowledge from 


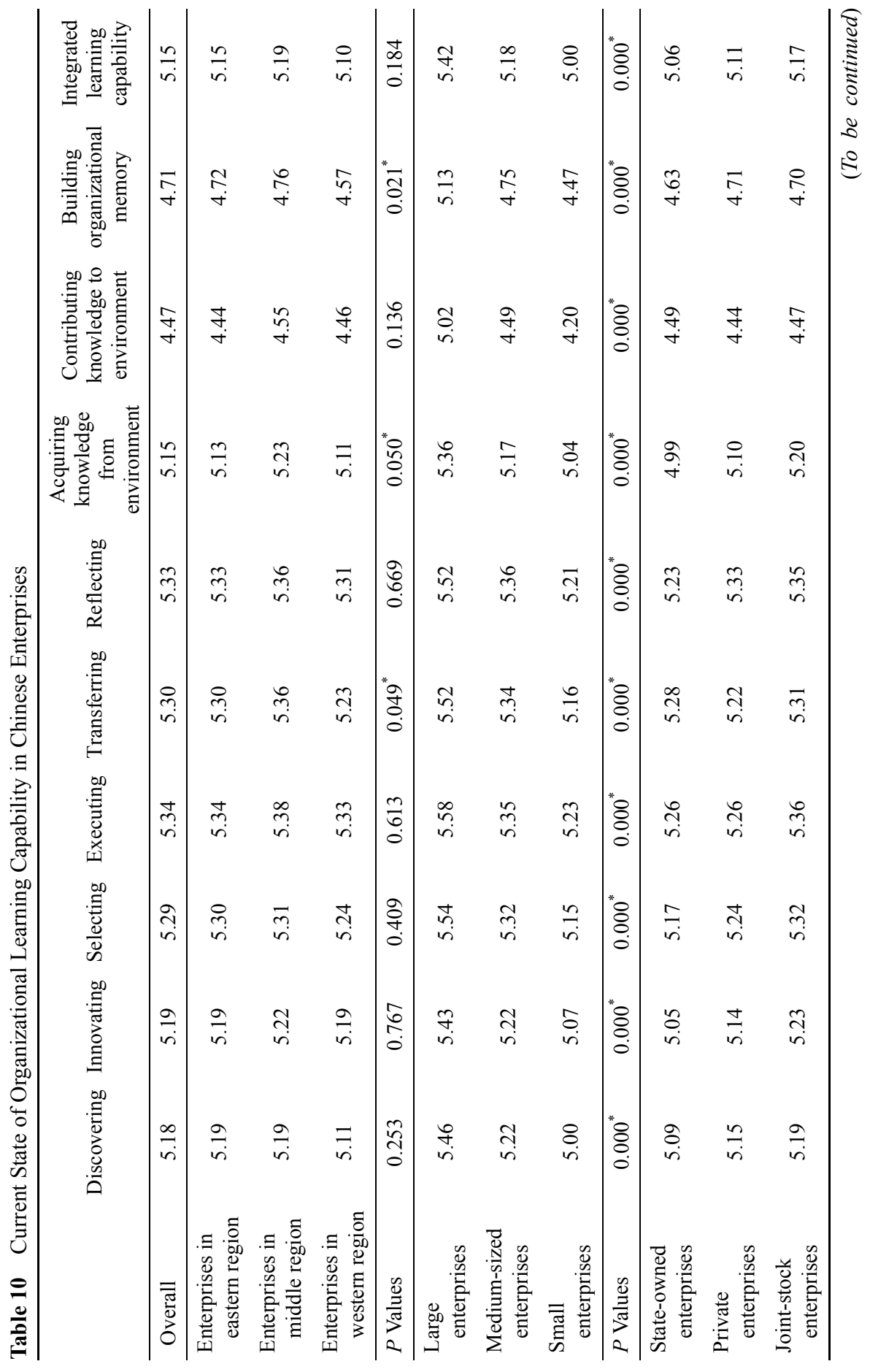




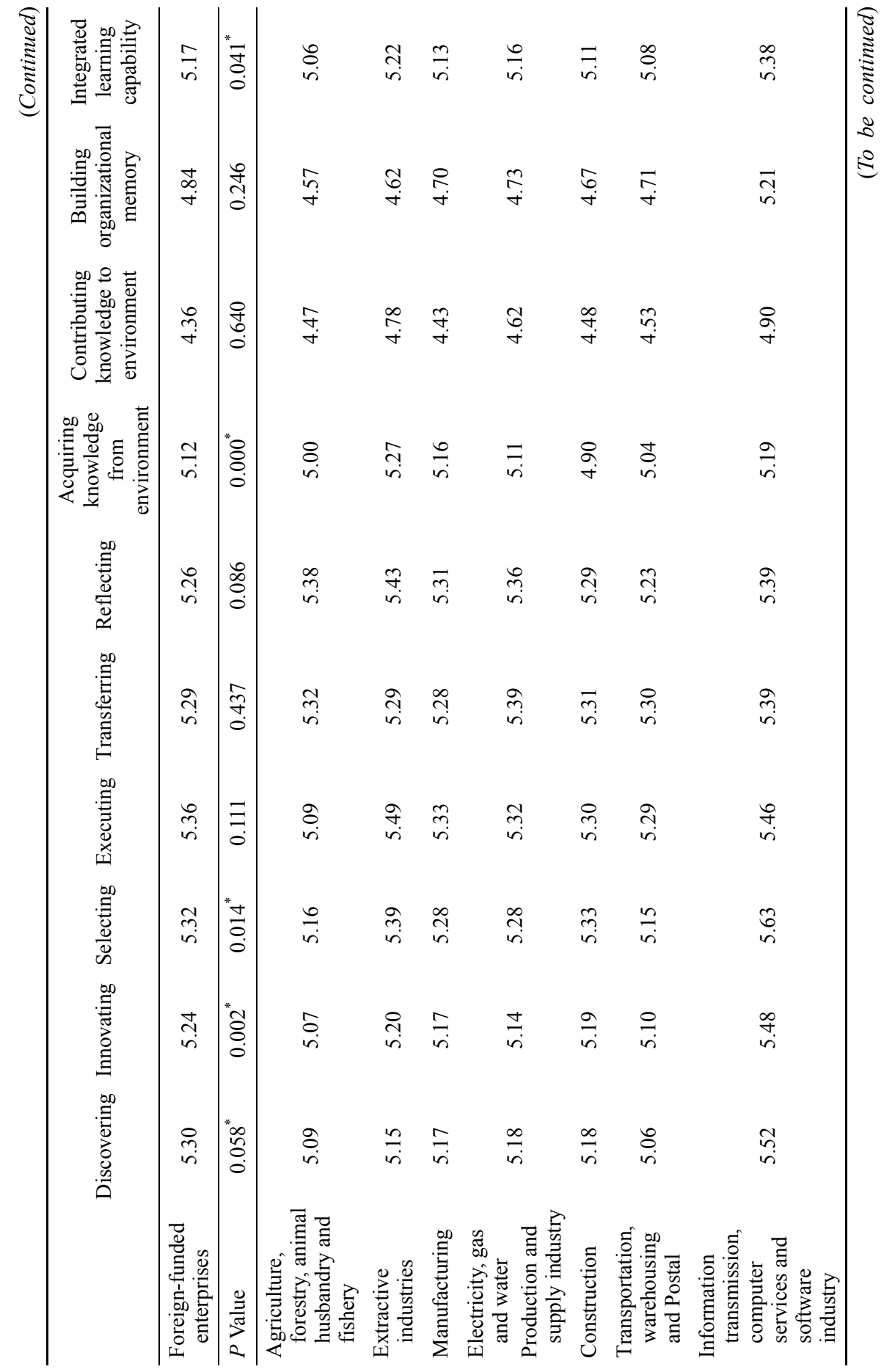




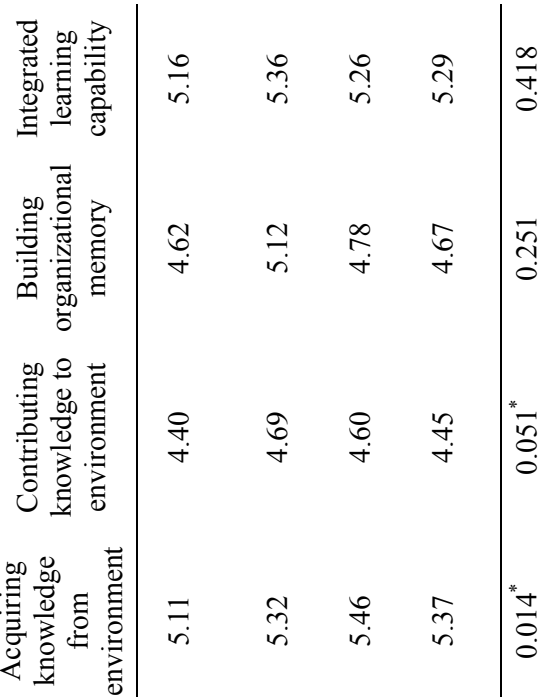

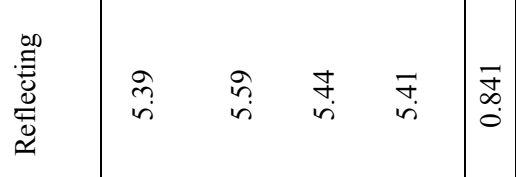

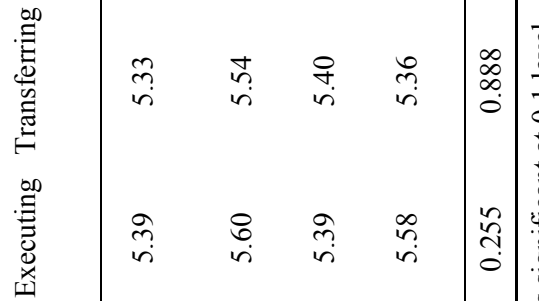

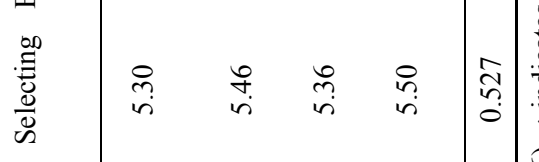

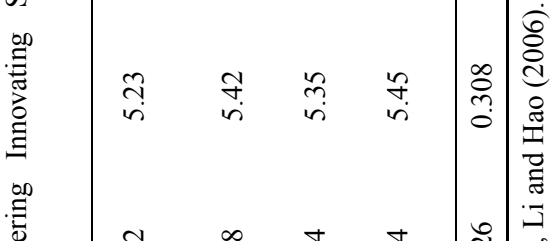

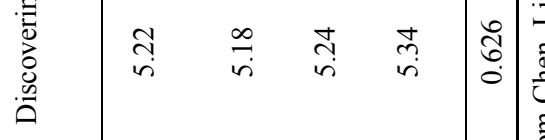

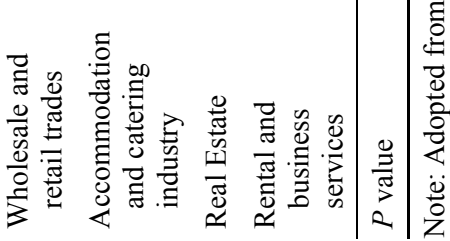




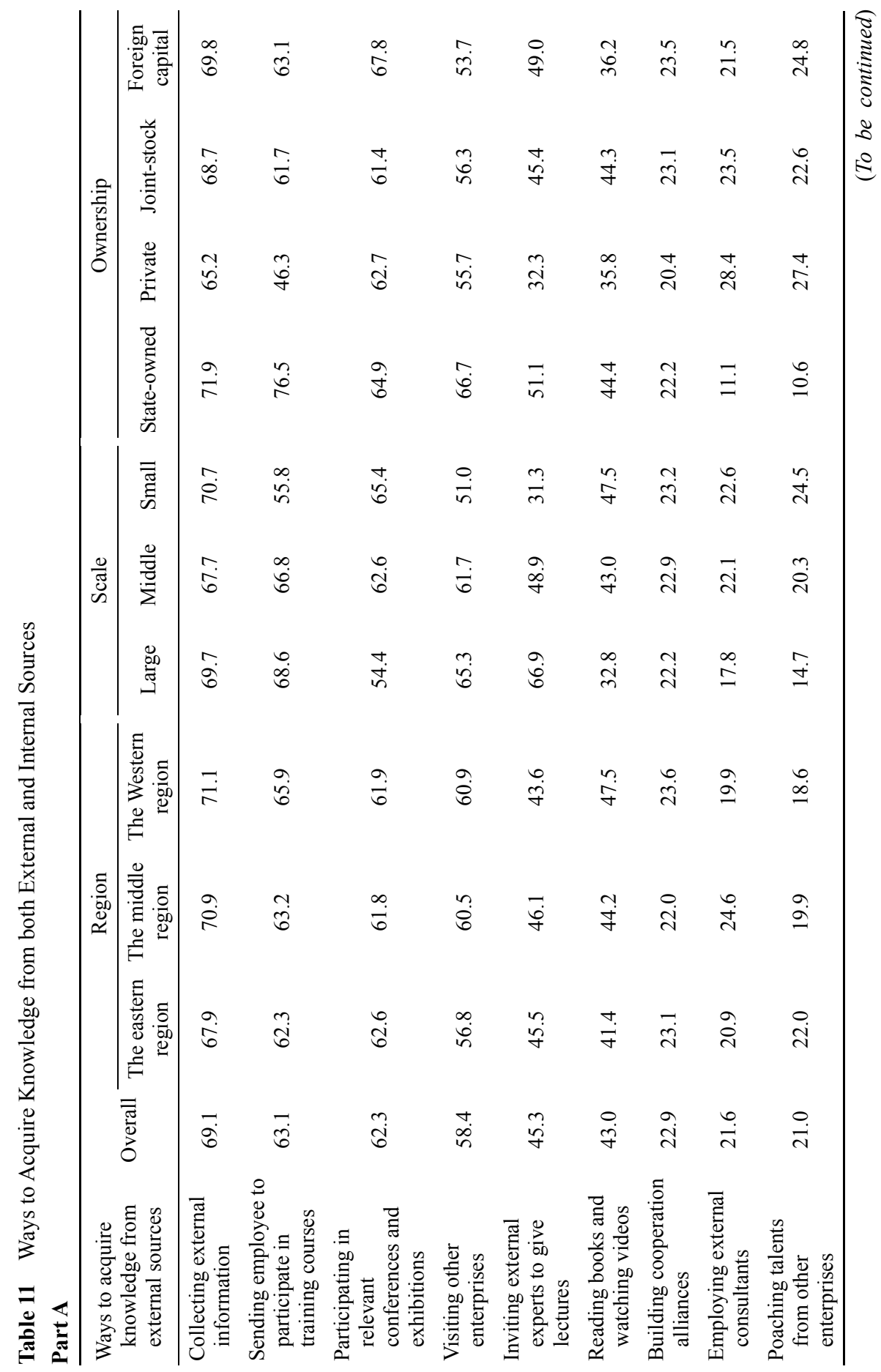




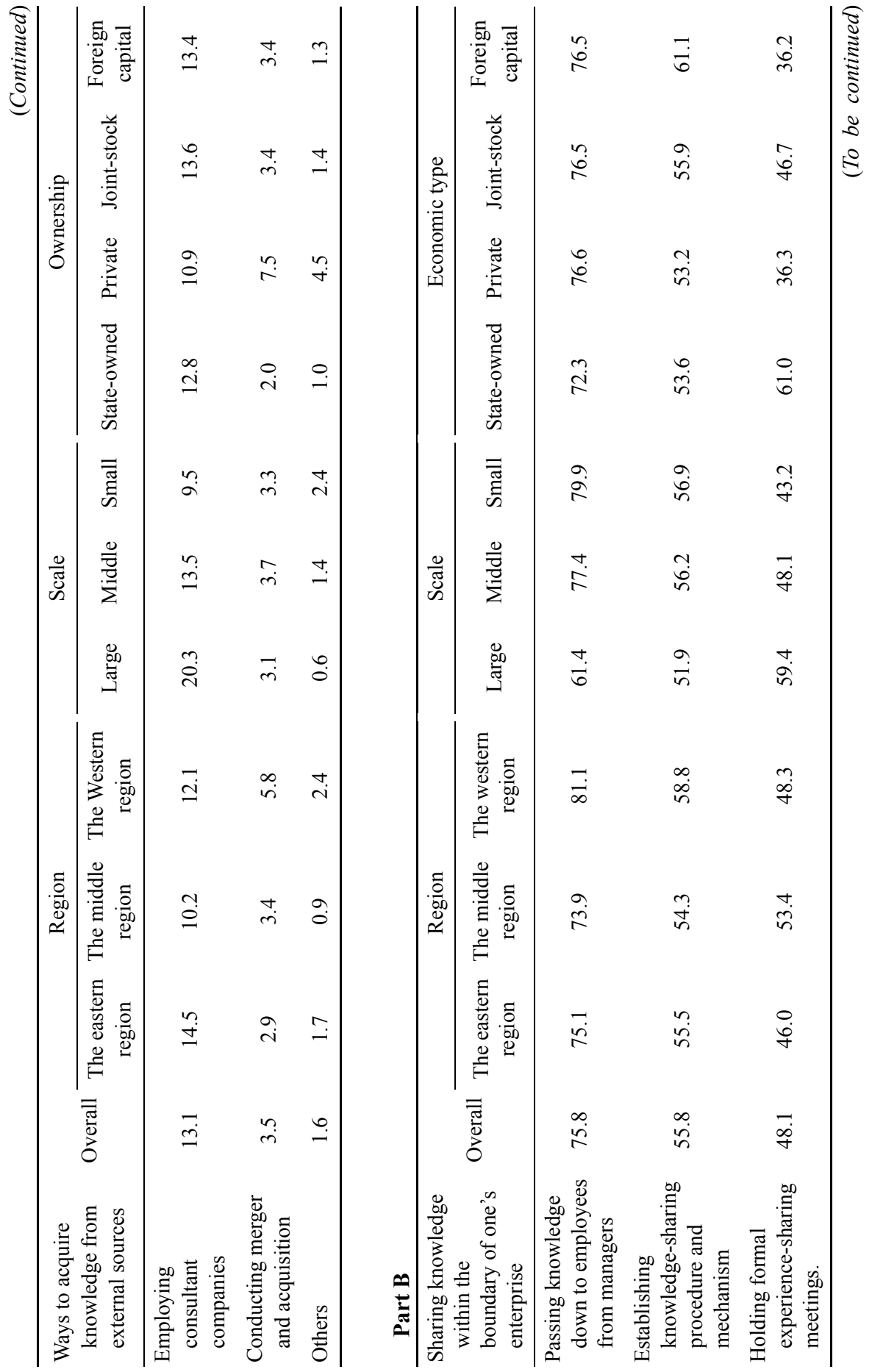




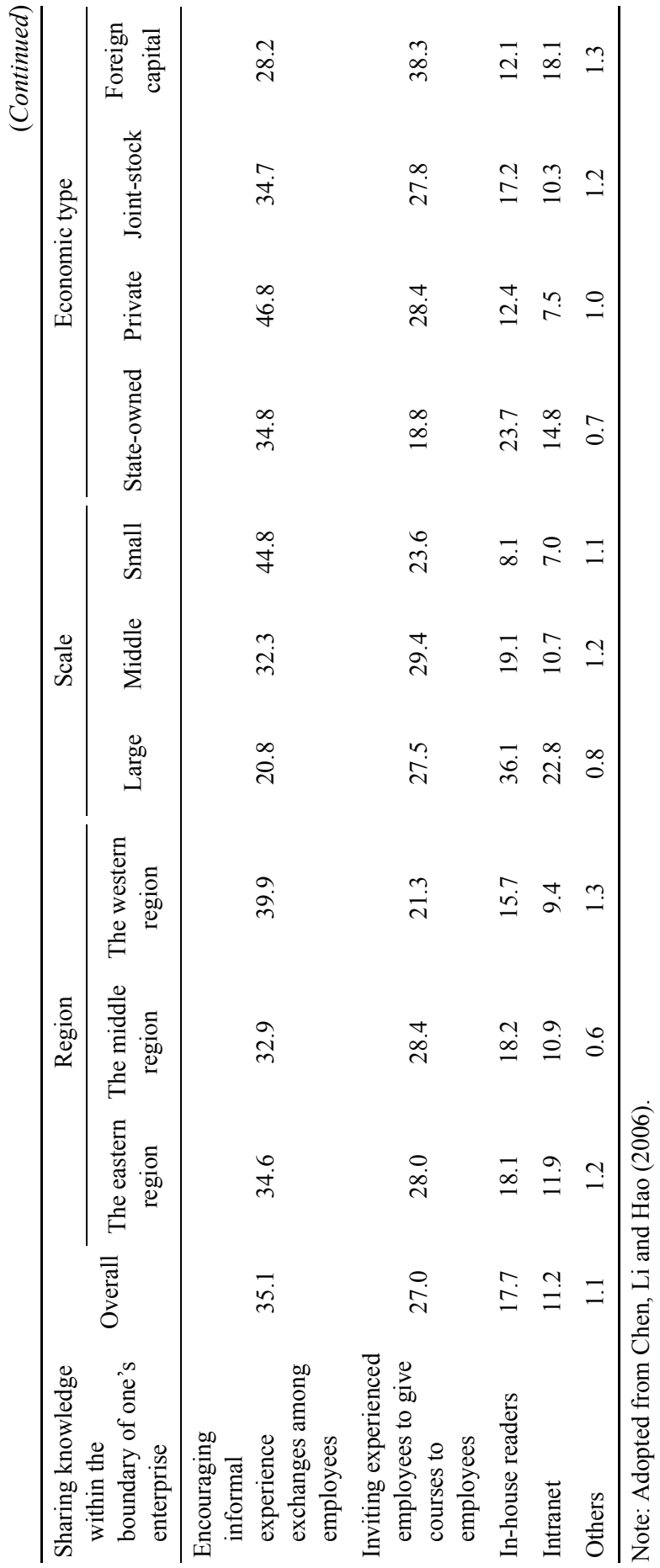


external environment. Some of the main knowledge acquisition approaches adopted by Chinese enterprises include collecting external information (69.1\%), sending employee to participate in training courses $(63.1 \%)$ and attending relevant conferences and exhibitions $(62.3 \%)$, etc.

Likewise, Chinese enterprises also have many ways to share knowledge within the boundary of enterprises. As shown in Table 11, many traditional knowledge-sharing methods (such as managers pass knowledge down to employees and experience sharing among employees) are still widely used in enterprises. Modern methods such as intranet exchange and internal publications need to be more widely applied in the future.

(4) Chinese enterprises need to increase their input in employee training, particularly in terms of adopting modern training approaches and perfecting mechanism of training performance evaluation.

The report reveals that the ratio of an enterprise's employee training expenditure to its annual sales revenue is positively related to its learning capability. Among the sampled enterprises, the average ratio in 2004 was $1.7 \%$ : $43.7 \%$ of sampled enterprises had a ratio smaller than $0.5 \%, 38.9 \%$ between 0.5 and $2 \%, 12.9 \%$ between 2 and $5 \%$, and $4.6 \%$ above $5 \%$. These data show that most of the Chinese enterprises still need to invest more in employee training.

As above, the level of employee training management in Chinese enterprises as a whole is quite satisfactory (5.11). Specifically, employee training has been widely emphasized among Chinese enterprise (5.67). Most of the employee training programs are established to meet the practical demands of employees (5.56). Employee training emphasizes both practical skills (5.18) and business ethics (5.35). However, Chinese enterprises still need to spend greater effort on combining employee training performance with individual promotion (4.79), as well as on applying of modern E-learning technology to training (4.11).

\section{Conclusion}

\subsection{Future Directions}

In the future, Chinese researchers need to further explore the inherent mechanism, antecedents, and consequences of organizational learning as well as the interrelationship between organizational learning itself and its antecedents and consequences. Equal emphasis should also be put on the interrelationship and mutual-transferability of organizational learning at the organizational, team and individual levels. As for research methods, a combination of case study, experiment and questionnaire methods are believed to be better able to gain a deeper understanding of the questions under study. Of course, Chinese researchers also need to pay more attention to the practical implication of 
organizational learning theories in Chinese enterprises to make the concepts of organizational learning and learning organizations more acceptable among Chinese enterprises. Likewise, Chinese researchers shall also strengthen their exchange and cooperation with western researchers to further promote the development of organizational learning in China.

\subsection{Practical Implications}

Over the past few years, Chinese enterprises have made tremendous progress in promoting organizational learning. Chinese managers are now more aware of the theories and practice of organizational learning and learning organizations. However, certain sub-capabilities (such as the building of organizational memory) of organizational learning need to be further improved. In addition, Chinese enterprises are supposed to adopt more advanced and effective means to promote the efficiency of knowledge acquisition from the external environment and experience sharing within organizations. Likewise, many enterprises also need to establish modern training and training performance evaluation mechanism to facilitate organizational learning and promote the establishment of learning organizations. We propose five suggestions on promoting organizational learning and establishing learning organizations in China: 1) Awareness. Chinese enterprises should be more aware of the changes in business environment both at home and abroad and maintain the foresightedness and strategic nature of their organizational learning activities; 2) Pragmatism. To give up any empty slogans and formalities and promote organizational learning in a down-to-earth way; 3 ) Holistic approaches. Chinese enterprises should promote organizational learning from all three levels and facilitate the complementariness of the three-level learning; 4) Continuous processes. Chinese enterprises need to systematize and routinize all kinds of organizational learning activities and help employees form learning habits. None of these can be achieved overnight; 5) Emphasis on communication. Chinese enterprises should pay more attention to communicating with peer enterprises home and abroad in order to learn from one another and to promote organizational learning in China.

\subsection{Intergration between Research and Practice}

In addition, researchers and practitioners should also cooperate closely to achieve a win-win situation. By doing so, enterprises can constantly enhance and facilitate their learning capabilities, while the academia can further promote the development of research on organizational learning. For example, in May 23 and 24, 2008, the "China's First Conference on Organizational Learning and Learning organizations Research and Practice" was successfully held in Beijing, 
attracted over a hundred attendants from both the academic and business world. Having greatly promoted the development of both organizational learning research and practice in China, the conference has demonstrated that a sound cooperation between practitioners and researchers is able to greatly promote both research and practice of organizational learning and learning organizations in China.

Acknowledgements This work is supported by the National Science Fund for Distinguished Young Scholars (No. 70625003), the National Natural Science Foundation (No. 70972024, $70890081,70572005,70272007,70321001$ ), the Humanities and Social Science Foundation of the Ministry of Education(No. 06JJD630013), and Doctoral Fund of Ministry of Education of China (No. 20090002110037). The authors would also like to give thanks to Qian Li for her help and contribution to this paper.

\section{References}

陈国权 (Chen Guoquan) (2001). 组织与环境的关系与组织学习 (Relationship between organization and its environment and organizational learning). 管理科学学报, 4(5): 39-49

陈国权 (Chen Guoquan) (2003). 人的知识来源模型记忆以及获取和传递知识过程的管理 (Studies on knowledge source model and management of knowledge acquisition and knowledge transferring process). 中国管理科学, 11(6): 86-94

陈国权 (Chen Guoquan) (2004). 学习型组织的组织结构特征与案例分析 (Characteristics of organizational structure of learning organizations and some case studies). 管理科学学报, 7(4): 56-67

陈国权 (Chen Guoquan) (2006). 组织行为学 (Organizational Behavior). 北京: 清华大学 出版社, 466-503

陈国权 (Chen Guoquan) (2007a). 团队学习和学习型团队: 概念、能力模型、测量及其对 团队绩效的影响 (Team learning and learning teams: Their concepts, measurements and impacts on team performance, and the capability models). 管理学报, 4(5): 602-609

陈国权 (Chen Guoquan) (2007b). 学习型组织的学习能力系统、学习导向人力资源管理系 统及其相互关系研究 (Studies on learning organizations: Organizational learning capability system, learning-oriented human resource management system and their relationships). 管理学报, 4(6): 719-728, 747

陈国权 (Chen Guoquan) (2008a). 复杂变化环境下个人的学习能力: 概念、模型、测量及 影响 (Individual learning capability in complex and dynamic business environment: Concept, capability model, measurement and impact on individual performance). 中国管理 科学, 16(1): 147-157, 747

陈国权 (Chen Guoquan) (2008b). 学习型组织的学习能力系统、学习导向人力资源管理系 统及其相互关系研究 (Learning organizations holistic system: Composition and relationship between its organizational system and capability system). 管理学报, 5(6): $832-840$

陈国权，李兰，郝大海，潘建成，彭泗清 (Chen Guoquan, Li Lan, Hao Dahai, Pan Jiancheng, Peng Siqing) (2006). 企业学习: 现状、问题, 以及对创新和竞争优势的影响 (Enterprises' learning: Status, problems and influences on creativity and competitive advantage). 管理世界, (6): 92-100 
陈国权, 马萌 (Chen Guoquan, Ma Meng) (2000). 组织学习的过程模型研究 (Studies on the process model of organizational learning). 管理科学学报, 3(3): 15-23

陈国权, 郑红平 (Chen Guoquan, Zheng Hongping) (2005). 组织学习影响因素、学习能力 与绩效关系的实证研究 (Empirical study on relationship among organizational influential factors, learning capabilities and organizational performance). 管理科学学报, 8(1): 48-61

陈浩然, 李垣, 谢恩 (Chen Haoran, Li Yuan, Xie En) (2007). 不同技术条件下组织间学习 过程的模型分析 (Modeling of the inter-organizational learning process with various technological differences). 系统工程, 25(4): 53-58

储建勋, 汤书坤 (Chu Jianxun, Tang Shukun) (2006). 量子学习模型——对组织中隐形知 识顿悟学习的研究 (Quantum learning model: Insight learning of tacit knowledge in organizations). 科学学与科学技术管理, 27(8): 80-83

戴万稳, 赵曙明, 蒋建武 (Dai Wangwen, Zhao Shuming, Jiang Jianwu) (2007). 组织学习 的跨文化效应: 中国和荷兰的比较 (Cross-cultural impact on organizational learning: A comparative study between the Netherlands and China). 科学学研究, 25(3): 541-545

冯振环, 罗永泰 (Feng Zhenhuan, Luo Yongtai) (2005). 虚拟性学习团队合作伙伴选择的 结构化系统解决方案 (The structured and systematic solution of partner selection of virtual learning team). 科学学与科学技术管理, 26(2): 126-129

郝宇, 罗永泰 (Hao Yu, Luo Yongtai) (2003). 高新技术企业虚拟性学习团队构建研究 (A study on constructing virtual learning team in high tech enterprises). 科学学与科学技术管 理, 24(6): 112-114

胡汉辉, 潘安成 (Hu Hanhui, Pan Ancheng) (2006). 组织知识转移与学习能力的系统研究 (Systemic study on organizational knowledge transfer and learning capability). 管理科学学 报, 9(3): 81-87

蒋春燕, 赵曙明 (Jiang Chunyan, Zhao Shuming) (2006). 社会资本和企业家精神与绩效的 关系: 组织学习的中介作用一一江苏与广东新型企业的实证研究 (The relationship between social capital, company enterprise and company performance: The medium role of organizational learning - A case study of the new and developing enterprises in Jiangsu and Guangdong). 管理世界, (10): 90-99

李丹 (Li Dan) (2007). 我国企业组织学习能力与绩效关系研究——基于对 201 家企业的 实证分析 (A study on relationship between learning capability and performance of Chinese companies: Empirical study on 201 companies). 工业技术经济, 26(5): 72-75

李炏, 任胜钢, 魏峰 (Li Yi, Ren Shenggang, Wei Gang) (2006). 组织学习方式对管理创新 成效的影响 (How organizational learning style influences the performance of management innovation). 中国软科学, (7): 121-130

廖冰, 胡新平, 金健斌 (Liao Bing, Hu Xinping, Jin Jianbin) (2006). 虚拟团队学习的金字 塔模型探讨 (A study on pyramidal model of virtual learning team). 科学管理研究, 24(7): $152-154$

刘石兰 (Liu Shilan) (2007). 市场导向、学习导向对组织绩效作用的影响一以产品创新 为中介变量 (Market orientation, learning orientation and organizational performance: An integrating research through product innovation). 科学学研究, 25(2): 301-305

刘希宋, 张长涛, 战歌 (Liu Xisong, Zhang Changtao, Zhan Ge) (2002). 企业产品开发团队 学习模型研究 (A study on learning model of product development team). 科学学与科学 技术管理, 23(1): 59-61

刘怡, 高山行 (Liu Yi, Gao Shanxing) (2007). IOS 中信任、学习与组织绩关系的实证研究 (The role of trust and learning in firm performance in inter-organizational systems). 科学学 研究, 25(6): 1178-1182

卢兵, 岳亮, 廖柇武 (Lu Bing, Yue Liang, Liao Xiuwu) (2006). 组织通过外部学习进行隐 
性知识转移的模型转移 ( Model research on tacit knowledge transfer of an organization by its external learning). 系统工程理论与实践, (10): 35-43

陆佳芳, 时勘 (Lu Jiafang, Shi Kan) (2004). 影响团队学习的人际因素研究 (Contextual factors affecting team learning). 管理学报, 1(3): 316-320

罗永泰 (Luo Yongtai) (2006). 虚拟型学习团队人力资源的层次界定 (Level defining of human resource of virtual learning team). 当代财经, (4): 75-82

彭说龙, 谢洪明, 陈春辉 (Peng Shuolong, Xie Hongming, Chen Chunhui) (2005). 环境互 动、组织学习与组织绩效的关系研究 (A study on the relationships between environmental turbulence,organizational learning and organizational performance). 科学学与科学技术管 理, 26(11): 106-110

施杨, 成晓芳, 李南 (Shi Yang, Cheng Xiaofang, Li Nan) (2007). 团队知识扩散的行为难 题与组织学习的内在逻辑 (Behavior problem of team knowledge spread and organizational learning logic). 科学学与科学技术管理, 28(5): 88-91

唐建生, 和金生 (Tang Jiansheng, He Jinsheng) (2005). 组织学习与个人学习的知识发酵 模型研究 (The knowledge fermenting models of organizational learning and individual learning). 科学管理研究, 23(1): 85-88

唐宁玉, 王重鸣 (Tang Ningyu, Wang Chongming) (2007). 虚拟团队学习效能: 社会认知 因素的影响 (Effectiveness of virtual team learning: The influence of social cognitive factors). 心理科学, 30(1): 227-231

唐宁玉, 朱晓妹 (Tang Ningyu, Zhu Xiaomei) (2006). 虚拟团队学习效能: 一个研究框架 (Effectiveness of virtual team learning: A research framework). 华东交通大学学报, 26(3): 28-32

魏明, 仲伟周, 赵海峰 (Wei Ming, Zhong Weizhou, Zhao Haifeng) (2005). 组织学习中信 息技术的功能 (The function of information technology in organizational learning). 科学 学与科学技术管理, 26(1): 133-137

吴价宝 (Wu Jiabao) (2003). 基于组织学习的企业核心能力形成机理 (The formation mechanism of the core competence based on organizational learning). 中国软科学, 25(6): $1178-1182$

肖余春 (Xiao Yuchun) (2004). 学习型团队三维特征结构与团队效能关系的现场试验研 究 (An experimental research on the relationship between the three-dimensional feature structure and team effectiveness of learning teams). 心理科学, 27(2): 471-473

谢洪明 (Xie Hongming) (2005). 市场导向、组织学习与组织绩效的关系研究 (A study on the relationships among market orientation, organizational learning and organizational performance). 科学学研究, 23(4): 517-524

谢洪明, 刘常勇, 陈春辉 (Xie Hongming, Liu Changyong, Chen Chunhui) (2006). 市场导 向与组织绩效的关系: 组织学习与创新的影响 (The relationship between being market-oriented and organizational performance: Organizational the learning effect of and innovation-A case study of the enterprises in the Pearl River Delta Region). 管理世界, (2): 80-94,143

谢洪明, 吴隆增, 王成, 葛志良 (Xie Hongming, Wu Longzeng, Wang Cheng, Ge Zhiliang) (2006). 组织学习的前因后果: 一个新的理论框架 (Antecedents and consequences of organizational learning: A new theoretical framework). 科学学与科学技术管理, 26(8): $161-168$

于海波, 方俐洛, 凌文轻 (Yu Haibo, Fang Liluo, Ling Wenquan) (2004a). 组织学习整合理 论模型 (Integrated theory of organizational learning model). 心理科学进展, 12(2): $246-255$

于海波, 方俐洛, 凌文轻 (Yu Haibo, Fang Liluo, Ling Wenquan) (2004b). 组织中学习与 个人学习策略演化及其案例研究 (The evolution of learning strategies in organizations 
and a case study). 心理科学进展, 25(5): 60-64

于海波, 方俐洛, 凌文辁 (Yu Haibo, Fang Liluo and Ling Wenquan) (2006). 企业组织的学 习结构 (The construct of organizational learning of Chinese companies). 心理学报, 38(4): 590-597

于海波, 方俐洛, 凌文辁 (Yu Haibo, Fang Liluo, Ling Wenquan) (2007). 组织学习及其作 用机制的实证研究 (Empirical study on organizational learning and its effect mechanism of Chinese enterprises). 心理学报, 10(5): 48-61

于海波, 郑晓明, 方俐洛, 凌文轻 (Yu Haibo, Zheng Xiaoming, Fang Liluo, Ling Wenquan) (2007). 组织学习内部推动因素的结构及其与组织学习取向的关系 (Study on facilitating factors of organizational learning and its relationship with organizational learning orientations of Chinese enterprises). 科学学与科学技术管理, 28(12): 145-150

袁静, 姚陆锋, 郑春东 (Yuan Jing, Yao Lufeng, Zheng Chundong) (2005). 知识惯性与组 织学习 (Knowledge inertia and organizational learning). 科学管理研究, 23(1): 81-84

张钢, 于小涵 (Zhang Gang, Yu Xiaohan) (2005). 组织网络化发展中的学习机制与创新效 率 (Learning mechanism and innovating efficiency in process of organizational networking development). 科研管理, 26(6): 87-93

张毅, 张子刚 (Zhang Yi, Zhang Zigang) (2005). 企业网络组织间学习过程的二维模型 (A two-dimension model of inter-organizational learning process in inter-firm network). 科学 学与科学技术管理, (9): 67-71

赵慧群，陈国权，付悦 (Zhao Huiqun, Chen Guoquan, Fu Yue) (2008). 团队学习心理准备 模型 (A conceptual model on team members psychological readiness for learning-A case study). 科学学与科学技术管理, 29(6): 182-187

周立新 (Zhou Lixin) (2007). 组织间学习、关系治理与家族企业网络化成长一一基于重庆 和浙江两省市家族企业的实证 (Inter-organizational learning, relationship governance and network growth of family firms: Empirical study on family firms in Chongqing and Zhejiang). 学海, (3): 122-129

朱瑜, 王痽飞, 蓝海林 (Zhu Yu, Wang Yanfei, Lan Hailin) (2007). 组织学习、组织创新与 企业核心能力关系研究 (An empirical study on interaction among organizational learning, organizational innovation and organizational core competence). 科学学研究, 25(3): $536-540$ 